Volume 1 Nomor 1, Februari 2016, halaman 37-42

\title{
PENGARUH MODEL ADVANCE ORGANIZER DENGAN PETA KONSEP UNTUK MENINGKATKAN KEMAMPUAN STRATEGIC COMPETENCE MATEMATIS SISWA SMP
}

\author{
Mellawaty \\ Universitas Wiralodra, mellatristiana78@gmail.com
}

\begin{abstract}
ABSTRAK
Strategic competence matematis merupakan salah satu fokus mathematical proficiency. Akan tetapi pada kenyataannya masih kita jumpai siswa yang kemampuan strategic competence matematisnya rendah. Salah satu alternatif pembelajaran yang dapat meningkatkan kemampuan strategic competence matematis siswa adalah model Advance Organizer dengan peta konsep. Penelitian ini bertujuan untuk mengetahui peningkatan kemampuan strategic competence matematis siswa yang memperoleh pembelajaran model Advance Organizer dengan peta konsep dan siswa yang memperoleh pembelajaran metode ekspositori. Penelitian ini menggunakan metode eksperimen. Populasi dalam penelitian ini adalah siswa kelas VII SMP Negeri 1 Kroya Kabupaten Indramayu dan diambil dua kelas secara acak menurut kelas sebagai sampel. Instrumen yang digunakan dalam penelitian ini adalah tes kemampuan strategic competence matematis. Berdasarkan analisis data hasil penelitian, diperoleh kesimpulan bahwa, peningkatan kemampuan strategic competence matematis siswa yang memperoleh pembelajaran model Advance Organizer dengan peta konsep lebih baik daripada siswa yang memperoleh pembelajaran metode ekspositori.
\end{abstract}

Kata Kunci: Advance Organizer, Peta Konsep, Strategic Competence.

\section{ABSTRACT}

Strategic mathematical competence is one focus of mathematical proficiency. But in reality they encountered students who are low mathematical ability of strategic competence. One alternative learning that can improve students strategic competence mathematical is a model Advance Organizer with a concept map. This study aims to determine the increase in strategic mathematical competence capability of students who received Organizer Advance model learning with concept maps and students who obtain teaching expository method. This study used an experimental method. The population in this study were students of class VII SMP Negeri 1 Kroya Indramayu and taken two classes at random according to the class as a sample. Instruments used in this research is test the ability of strategic mathematical competence. Based on the analysis of research data, we concluded that, by enhancing the strategic competence of students who obtain a mathematical model study Advance Organizer to map the concept better than students who received learning expository method.

Keywords: Advance Organizer, Concept Map, Strategic Competence. 
How to Cite: Mellawaty. (2016). Pengaruh Model Advance Organizer dengan Peta Konsep untuk Meningkatkan Kemampuan Strategic Competence Matematis Siswa SMP. Mathline: Jurnal Matematika dan Pendidikan Matematika, Vol.1, No.1, 37-42.

\section{PENDAHULUAN}

Guru memiliki peran penting dalam proses pembelajaran di kelas, diantaranya guru bertanggung jawab menyusun rencana kegiatan pembelajaran, melaksanakan kegiatan pembelajaran, mengevaluasi, menganalis hasil evaluasi, dan melakukan tindak lanjut hasil pembelajaran. Oleh karena itu, gurulah yang akan menjadi "sutradara" sebagai penentu keberhasilan siswa dalam mencapai hasil belajar serta menumbuhkembangkan nilai-nilai kehidupan.

Keberhasilan proses belajar mengajar dapat dilihat dari keberhasilan siswa yang mengikuti kegiatan pembelajaran, yaitu dari tingkat pemahaman, penguasaan materi, dan kemampuan pemecahan masalah siswa. Semakin tinggi kemampuan pemahaman, penguasaan materi dan kemampuan pemecahan masalah siswa semakin tinggi pula tingkat keberhasilan pembelajaran. Banyak faktor yang mempengaruhi keberhasilan belajar siswa sebagaimana dinyatakan oleh Ruseffendi (2006),

Terdapat beberapa faktor yang dapat mempengaruhi keberhasilan siswa belajar. Faktor-faktor yang hampir sepenuhnya tergantung pada murid antara lain: kecerdasan anak, kesiapan anak, dan bakat anak. Sedangkan faktor yang tergantung pada guru antara lain: kemampuan (kompetensi), suasana belajar dan kepribadian guru sebagai manusia model. Dan satu faktor lain di luar kemampuan murid maupun guru, yaitu kondisi masyarakat.

Konsep matematika tersusun secara hierarkis, artinya dalam mempelajari matematika, pemahaman konsep sebelumnya menjadi prasyarat untuk dapat memahami konsep selanjutnya. Oleh karena itu penyajian materi dalam matematika harus benarbenar diperhatikan. Dalam hal ini peran guru sebagai seorang pendidik sangat penting dalam mendukung keberhasilan belajar siswa. Gintings (2008) menyatakan, "Pada hakekatnya inti dari proses pendidikan adalah belajar dan pembelajaran dalam mana guru berperan selaku sutradara, aktor, manajer dan sekaligus merangkap sebagai penilai".

Berikut ini mathematical proficiency yang diklasifikasikan oleh Killpatrick et.al (2001), meliputi lima strands (aspek), yaitu: 
1. Conceptual understanding - comprehension of mathematical concepts, operations, and relations.

2. Procedural fluency - skill in carrying out procedures flexibly, accurately, efficiently, and appropriately.

3. Strategic competence - ability to formulate, represent, and solve mathematical problems.

4. Adaptive reasoning - capacity for logical thought, reflection, explanation, and justification.

5. Productive disposition - habitual inclination to see mathematics as sensible, useful, and worthwhile, coupled with a belief in diligence and one's own efficacy.

Siswa membutuhkan pengalaman dan latihan dalam merumuskan masalah sebagaimana halnya dalam memecahkan masalah, mereka harus mengetahui berbagai macam strategi pemecahan masalah serta mengetahui strategi mana yang berguna dalam menyelesaikan permasalahan tersebut. Ketika menghadapi suatu permasalahan, siswa harus mampu memformulasikan masalah tersebut, memilih informasi-informasi yang relevan dengan masalah tersebut, serta mengetahui bagaimana cara dan strategi yang harus dipilih untuk diterapkan dalam memecahkan masalah tersebut.

Berkaitan dengan hal tersebut, terdapat suatu model pembelajaran konstruktivistik yang dapat dikatakan mirip dengan model tradisional dalam konteks metode penyampaian materi, yaitu model pembelajaran Advance Organizer. Model Advance Organizer ini diilhami oleh teori belajar bermakna (meaningful learning) dari David Ausubel. Meskipun metode penyampaian materinya melalui ceramah, pembelajaran Advance Organizer dapat mencapai kebermaknaan dalam pembelajaran. Pemilihan penggunaan model Advance Organizer karena dalam pelaksanaannya dapat meningkatkan struktur kognitif siswa.

Model pembelajaran Advance Organizer merupakan model pembelajaran yang diciptakan oleh David Ausubel pada tahun 1960-an. Model pembelajaran Advance Organizer mengarahkan pada siswa ke materi yang akan mereka pelajari dan menolong mereka untuk mengingat kembali informasi yang berhubungan yang dapat digunakan dalam membantu menanamkan pengetahuan baru.

Namun demikian, Ausubel belum menentukan cara yang sesuai yang dapat digunakan guru untuk mengetahui apa yang telah diketahui oleh siswa. Dahar (2011) menyatakan bahwa berkenan dengan hal ini, Novak dalam bukunya Learning How to Learn mengemukakan bahwa cara untuk mengetahui konsep-konsep yang telah dimiliki siswa dan agar belajar bermakna, dapat berlangsung dengan dilakukannya pertolongan peta konsep. 
Menurut Dahar (2011) peta konsep dikembangkan untuk menggali ke dalam struktur kognitif pelajar dan untuk mengetahui, baik bagi pelajar maupun guru, melihat apa yang telah diketahui pelajar. Hudojo dkk (Supratman, 2009) menyimpulkan bahwa peta konsep itu merupakan jaringan konsep yang antara konsep-konsep tersebut dihubungkan dengan proposisi. Proposisi tersebut bias berupa kata: mempunyai, adalah, merupakan, terdiri dari, mengandung, berasal dari, yaitu, bersifat, jika...maka..., dll. Proposisi menunjukkan keterpaduan dalam jaringan tersebut.

Dalam penelitian ini, kemampuan matematika yang akan diteliti adalah kemampuan strategic competence. Untuk menjadi seorang problem solver yang handal siswa harus belajar bagaimana cara untuk mengkonstruksi atau membuat model dari masalah, menemukan hubungan matematis, dan menemukan solusi baru pada saat diperlukan. Suatu karakteristik yang mendasar yang diperlukan secara keseluruhan dalam pemecahan masalah adalah fleksibilitas. Menurut Killpatrick et.al (2001) untuk membangun fleksibilitas dapat dilakukan dengan cara mengerjakan permasalahan tidak rutin yaitu permasalahan yang tidak segera diketahui cara menyelesaikannya, sehingga siswa perlu memahami permasalahan, menemukan metode yang tepat untuk mendapatkan solusi dan memecahkannya.

Menurut Killpatrick et.al (2001) indikator-indikator dari strategic competence yaitu:

a. Memahami situasi serta kondisi dari suatu permasalahan.

b. Menemukan kata-kata kunci serta mengabaikan hal-hal yang tidak relevan dari suatu permasalahan.

c. Menyajikan masalah secara matematik dalam berbagai bentuk.

d. Memilih penyajian yang cocok untuk membantu memecahkan permasalahan.

e. Menemukan hubungan matematik yang ada di dalam suatu masalah.

f. Memilih dan mengembangkan metode penyelesaian yang efektif dalam menyelesaikan suatu permasalahan.

g. Menemukan solusi dari permasalahan yang diberikan.

Tujuan penelitian ini adalah untuk mengkaji tentang peningkatan kemampuan strategic competence matematis siswa yang memperoleh pembelajaran model Advance Organizer dengan peta konsep.

\section{METODE PENELITIAN}

Dalam penelitian ini metode yang digunakan adalah metode eksperimen. Ruseffendi (2005) menyatakan bahwa penelitian eksperimen atau percobaan 
(experimental research) adalah penelitian yang benar-benar untuk melihat hubungan sebab-akibat. Dalam penelitian ini perlakuan terhadap kelas eksperimen yaitu siswa yang memperoleh pembelajaran model Advance Organizer dengan peta konsep. Sedangkan kelas kontrol menggunakan pembelajaran ekspositori. Desain penelitian yang digunakan adalah desain kelompok kontrol tes awal-tes akhir. Dalam desain ini terdapat dua kelas yang dipilih secara acak menurut kelas, yaitu kelas kontrol dan kelas eksperimen. Kemudian kedua kelas tersebut diberi tes awal untuk mengetahui kemampuan awal antara kelas eksperimen dan kelas kontrol sebelum diberikan pembelajaran. Tes akhir dilakukan setelah proses pembelajaran berlangsung dengan tujuan untuk mengetahui kemampuan strategic competence matematis siswa setelah mengalami pembelajaran.

Menurut Ruseffendi (2005), gambar desainnya adalah sebagai berikut:

$\begin{array}{llll}\text { A } & \mathrm{O} & \mathrm{X} & \mathrm{O} \\ \mathrm{A} & \mathrm{O} & & \mathrm{O}\end{array}$

Keterangan:

A : Subjek yang dipilih secara acak menurut kelas

O : Tes awal (pretes) $=$ Tes akhir (postes)

X : Perlakuan (dalam penelitian ini adalah pembelajaran model Advance Organizer dengan peta konsep)

Penelitian ini akan dilakukan di SMPN 1 Kroya, Indramayu. Dari beberapa kelas VII yang ada di SMP Negeri 1 Kroya, dipilih dua kelas yang kemudian dijadikan sampel. Instrumen yang digunakan dalam penelitian ini adalah tes dan non-tes. Dan instrumen tes yang digunakan adalah tipe uraian karena untuk menguji kemampuan strategic competence matematis diperlukan soal bentuk uraian.

\section{HASIL PENELITIAN DAN PEMBAHASAN}

Tabel 1.1. Uji Kesamaan Rata-Rata Indeks Gain Kelas Eksperimen dan Kelas Kontrol

\begin{tabular}{|c|c|c|c|c|c|c|c|c|c|c|}
\hline \multicolumn{11}{|c|}{ Independent Samples Test } \\
\hline & & $\begin{array}{l}\text { Leve } \\
\text { Test } \\
\text { Equal } \\
\text { Varia }\end{array}$ & $\begin{array}{l}\text { ne's } \\
\text { for } \\
\text { ty of } \\
\text { cees }\end{array}$ & \multicolumn{7}{|c|}{ t-test for Equality of Means } \\
\hline & & & & & & & & & $\begin{array}{r}95 \% \text { Co } \\
\text { Interva } \\
\text { Differ }\end{array}$ & $\begin{array}{l}\text { fidence } \\
\text { of the } \\
\text { ence }\end{array}$ \\
\hline & & F & Sig. & $\mathrm{T}$ & df & $\begin{array}{l}\text { Sig. (2- } \\
\text { tailed) }\end{array}$ & $\begin{array}{c}\text { Mean } \\
\text { Difference }\end{array}$ & $\begin{array}{l}\text { Std. Error } \\
\text { Difference }\end{array}$ & Lower & Upper \\
\hline \multirow[t]{2}{*}{$\begin{array}{l}\text { Nilai } \\
\text { Gain }\end{array}$} & $\begin{array}{l}\text { Equal variances } \\
\text { assumed }\end{array}$ & .295 & .589 & 2.711 & 60 & .009 & .11032 & .04069 & .02893 & .19171 \\
\hline & $\begin{array}{l}\text { Equal variances } \\
\text { not assumed }\end{array}$ & & & 2.711 & 59.781 & .009 & .11032 & .04069 & .02893 & .19172 \\
\hline
\end{tabular}


Berdasarkan analisis data hasil penelitian, diperoleh bahwa kemampuan strategic competence matematis siswa yang menggunakan model pembelajaran Advance Organizer dengan peta konsep lebih baik daripada kemampuan strategic competence matematis siswa yang menggunakan metode ekspositori. Hal ini disebabkan karena pada model pembelajaran Advance Organizer dengan peta konsep dapat memperkuat struktur kognitif siswa. Sesuai dengan apa yang dinyatakan oleh Ausubel (dalam Joyce et.al, 2011) bahwa model Advance Organizer dirancang untuk memperkuat struktur kognitif siswa, pengetahuan mereka tentang pelajaran tertentu dan bagaimana mengelola, memperjelas, dan memelihara pengetahuan tersebut dengan baik. Selain itu, dalam pembelajaran Advance Organizer dengan peta konsep, siswa mempunyai kesempatan untuk berperan aktif dalam kegiatan pembelajaran, sehingga pembelajaran menggunakan model Advance Organizer dengan peta konsep dapat meningkatkan kemampuan strategic competence matematis siswa.

\section{KESIMPULAN}

Berdasarkan data penelitian dan analisis data serta pengujian hipotesis dalam penelitian ini, maka dapat disimpulkan bahwa, peningkatan kemampuan strategic competence matematis siswa yang memperoleh pembelajaran model Advance Organizer dengan peta konsep lebih baik daripada siswa yang memperoleh pembelajaran metode ekspositori.

\section{DAFTAR PUSTAKA}

Dahar, R. W. (2011). Teori-Teori Belajar dan Pembelajaran. Jakarta: Erlangga.

Gintings, A. (2008). Esensi Praktis Belajar dan Pembelajaran. Bandung: Humaniora.

Joyce, B. \& Weil, M. \& Calhoun, E. (2011). Models of Teaching (Model-Model Pengajaran Edisi Kedelapan Diterjemahkan oleh Ahmad Fawaid dan Ateilla Mirza). Yogyakarta: Pustaka Pelajar Johnson, E. B. (2008). Contextual Teaching and Learning: Menjadikan Kegiatan Belajar dan Mengajar Mengasyikan dan Bermakna. Bandung: Mizan Learning Center.

Killpatrick, J. et al. (2001). Adding It Up: Helping Children Learn Mathematics. [Online]. Tersedia: http://nap.edu/openbook.php?record id=9822\&page=121 [13 januari 2012].

Ruseffendi, E.T. (2005). Dasar-Dasar Penelitian Pendidikan \& Bidang Non-Eksakta Lainnya. Bandung: Tarsito.

Ruseffendi, E.T. (2006). Pengantar kepada Membantu Guru Mengembangkan Kompetensinya dalam Pengajaran Matematika untuk Meningkatkan CBSA. Bandung: Tarsito.

Supratman. (2009). Meningkatkan Kemampuan Pemecahan Masalah Matematika Melalui Pembelajaran dengan Peta Konsep. Tesis pada PPS UPI. Bandung: Tidak Diterbitkan 